\title{
Scleroramularia gen. nov. associated with sooty blotch and flyspeck of apple and pawpaw from the Northern Hemisphere
}

\author{
Huanyu Li • Guangyu Sun • Jean Carlson Batzer • \\ Pedro W. Crous • Johannes Z. Groenewald • \\ Aziz Karakaya • Mark L. Gleason
}

Received: 28 October 2010 / Accepted: 4 November 2010/Published online: 3 December 2010

(C) The Author(s) 2010. This article is published with open access at Springerlink.com

\begin{abstract}
Scleroramularia is proposed as a new hyphomycetous fungal genus associated with sooty blotch and flyspeck (SBFS) blemishes of apple and pawpaw fruit in the Northern Hemisphere. Morphologically the genus closely resembles Ramularia (Mycosphaerellaceae), based on its chains of hyaline conidia, with thickened, darkened, somewhat refractive conidiogenous loci. Scleroramularia is distinguished by forming black sclerotial bodies in culture, and having conidial chains that do not quickly disarticulate as observed in Ramularia. Based on the nuclear ribosomal DNA phylogeny (LSU), Scleroramularia represents an undescribed order in the Dothideomycetes, clustering between the Pleosporales and the Botryosphaeriales.
\end{abstract}

\section{H. Li $\cdot$ G. Sun $(\bowtie)$}

College of Plant Protection \& Shaanxi Key Laboratory

of Molecular Biology for Agriculture, Northwest A\&F University,

Yangling, Shaanxi 712100, People's Republic of China

e-mail: sgy@nwsuaf.edu.cn

J. C. Batzer · M. L. Gleason

Department of Plant Pathology, Iowa State University,

Ames, IA 50011, USA

P. W. Crous $\cdot$ J. Z. Groenewald

CBS-KNAW Fungal Biodiversity Centre,

P.O. Box 85167, 3508 AD, Utrecht, the Netherlands

P. W. Crous

Microbiology, Department of Biology, Utrecht University,

Padualaan 8 ,

$3584 \mathrm{CH}$, Utrecht, The Netherlands

\section{A. Karakaya}

Faculty of Agriculture, Department of Plant Protection,

University of Ankara,

Dışkap1 06110 Ankara, Turkey
Further analysis of morphology in combination with DNA phylogeny of the nuclear ribosomal ITS region and partial translation elongation factor 1-alpha (TEF) gene sequences delimited five species. These include $S$. asiminae on Asimina triloba (pawpaw fruit) in the U.S.A., and four other species occurring on apple fruit, namely $S$. abundans (on a local cultivar in Ardeșen, Rize, Turkey), S. shaanxiensis (on 'Fuji' in China), S. pomigena (on 'Golden Delicious' in the U.S.A.), and S. henaniensis (on 'Fuji' in China, and 'Golden Delicious' and 'Gold Rush' in the U.S.A.). Morphologically these taxa can be distinguished based on a combination of culture characteristics and conidial morphology in vitro, which is reflected in a key to the species treated.

Keywords Anamorph ·SBFS · Taxonomy

\section{Introduction}

Sooty blotch and flyspeck (SBFS) is a complex of epiphytic fungi that cause late-season blemishes on fruit with waxy cuticles in humid regions worldwide (Batzer et al. 2005; Colby 1920; Williamson and Sutton 2000; Yang et al. 2010). Substantial economic losses for growers can result when these blemished fruit are downgraded from freshmarket to processing uses (Colby 1920; Díaz Arias et al. 2010). In general use, the term "flyspeck" refers to clusters of black, round to ovoid, sclerotium-like bodies without the presence of a visible mycelial mat, whereas "sooty blotch" designates colonies that form a mycelial mat with or without sclerotium-like bodies. Seven mycelial types have been delineated (Batzer et al. 2005). The compact 
speck mycelial type is characterised by relatively small and densely arranged sclerotium-like bodies that leave behind ring-shaped remnants when they are removed (Batzer et al. 2005). Two similar mycelial types, flyspeck and discrete speck, are distinguished from compact speck by having substantially larger and sparser sclerotium-like bodies (flyspeck), or absence of remnants when sclerotium-like bodies are removed (discrete speck) (Batzer et al. 2005).

Fungi in the SBFS complex are highly diverse, comprising as many as 78 putative species based on genetic and morphological evidence; most of these (68 species) grouped within the Capnodiales, Dothideomycetes (Batzer et al. 2005, 2008; Díaz Arias et al. 2010; Frank et al. 2010; Johnson and Sutton 1994; Johnson et al. 1996; Li et al. 2010; Ma et al. 2010, Yang et al. 2010; Zhai et al. 2008; Zhang et al. 2007, 2009). To date, only 24 of these species have been assigned Latin binomials. Several additional putative species reside in Dothideomycetes but could not be placed to the order level, such as Sterile mycelia sp. FG6, Ramularia sp. CS2 and Sybren sp. CS1(Díaz Arias et al. 2010).

Some SBFS fungal groups, although morphologically similar to named taxa, appear to be distinct. For example, Sporidesmajora, Houjia, and Phaeothecoidiella were recently distinguished from the previous "Xenostigmina," "Cercostigmina" and "Stigmina" SBFS fungi from China and the U.S. (Batzer et al. 2005; Yang et al. 2010). Furthermore, an investigation of SBFS fungi conducted in Germany and Slovenia resulted in naming of two additional genera, Microcyclospora and Microcyclosporella, from SBFS groups previously assigned as "Pseudocercospora" and "Pseudocercosporella" respectively (Batzer et al. 2005; Frank et al. 2010).

In the present study, seven isolates associated with compact speck colonies (Fig. 1) on apples collected from China, the U.S. and Turkey were shown to be morphologically and genetically similar to the previously reported SBFS putative species "Ramularia sp. CS2" and "Ramularia sp. P7"
(Batzer et al. 2005). Two additional isolates obtained from compact speck signs on pawpaw (Asimina triloba), a native tree fruit in North America, were also found to cluster in the same group. "Ramularia" spp. CS2 and P7 were initially named on the basis of morphological similarities with some Ramularia species (Batzer et al. 2005). However, the taxonomy of this "Ramularia" group in the SBFS complex has been problematic, due to its distant phylogenetic relationship with other known taxa in Mycosphaerellaceae based on LSU parsimony analysis (Batzer et al. 2005; Crous 2009; Crous et al. 2009a, b; Díaz Arias et al. 2010). The aim of this study was to resolve the taxonomic status of the "Ramularia" group in the SBFS complex by assessing nuclear ribosomal DNA sequences, a partial protein coding gene sequence and morphology.

\section{Materials and methods}

Isolates and scanning electron microscopy

Seven of the nine isolates in our study were obtained from apple (Malus $\times$ domestica) and two were from pawpaw (Asimina triloba). Apples with SBFS signs were collected in October of 2006 from orchards located near Lingbao city of Henan Province, and in Mei County of Shaanxi Province, China. Pure isolates were obtained following the protocol of Sun et al. (2003). One isolate was selected from each location. After apples with SBFS signs were harvested from orchards in Ardeșen, Rize, Turkey in November of 2008, colonies with subtending apple cuticle were excised, pressed, photographed, and shipped to Iowa State University, Ames, Iowa, U.S.A., and isolation was performed as described elsewhere (Batzer et al. 2005; Blaser et al. 2010). Two isolates from Turkey were included in this study, along with three isolates sampled from apple orchards in Kentucky, Massachusetts and New York, U.S.A., during a 2005 survey (Díaz Arias et al. 2010).
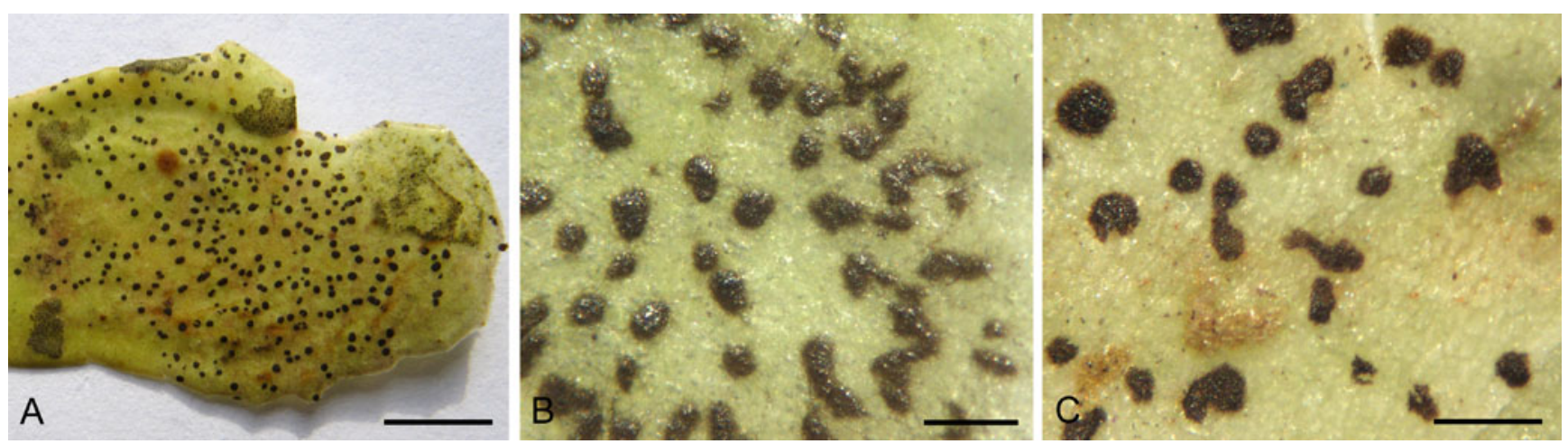

Fig. 1 Signs of SBFS on apple. A. Scleroramularia abundans. B. S. pomigena. C. S. henanensis. Scale bars: A=5 mm, B=1 mm, C=0.5 mm 
The two isolates from pawpaw fruit collected near Iowa City, Iowa, in 2007 were obtained as described for apple (Batzer et al. 2005). Segments of peels exhibiting SBFS signs were pressed between paper towels until dry and preserved; specimens on apple peels were deposited at the Iowa State University Herbarium, Ames, Iowa.

Single-conidial isolates were established on $2 \%$ malt extract agar (MEA), 2\% potato-dextrose agar (PDA), oatmeal agar (OA; Crous et al. 2009c), and subsequently incubated at $25^{\circ} \mathrm{C}$ under near-ultraviolet light to promote sporulation. Reference strains are maintained in the culture collection of the Centraalbureau voor Schimmelcultures (CBS-KNAW Fungal Biodiversity Centre), Utrecht, the Netherlands, and at Iowa State University (Table 1). Descriptions, nomenclature, and illustrations were deposited in MycoBank (Crous et al. 2004).

To clarify how conidia are produced in this group, and add information pertaining to the nature of their conidial hila and conidiogenous scars, scanning electron micrographs (SEM) were taken of two isolates from China. After cultures were maintained on PDA for 1 mo in darkness at room temperature, sterile cover slips with attached hyphae were fixed in 3\% glutaraldehyde and $1 \%$ osmium tetroxide in $0.1 \mathrm{M}$ cacodylate buffer ( $\mathrm{pH}$ 6.8), followed by a series of ethanol rinses; then the hyphae were dehydrated in a critical point drier, sputter-coated with gold, and examined under a scanning electron microscope (Joel JSM 6360LV) at accelerating voltages of 15 and $25 \mathrm{KV}$ (Zhang et al. 2009).

DNA isolation, amplification and phylogeny

Genomic DNA was isolated from fungal mycelium grown on MEA, using the UltraClean ${ }^{\mathrm{TM}}$ Microbial DNA Isolation Kit (Mo Bio Laboratories, Inc., Solana Beach, CA, U.S.A.) according to the manufacturer's protocols. Part of the nuclear rDNA operon spanning the $3^{\prime}$ end of the $18 \mathrm{~S}$ nrRNA gene (SSU), the first internal transcribed spacer (ITS1), the 5.8S nrRNA gene, the second ITS region (ITS2) and the $5^{\prime}$ end of the 28S nrRNA gene (LSU) was amplified for some isolates as explained in Lombard et al. (2010) and partial translation elongation factor 1-alpha (TEF) gene sequences were determined as described in Bensch et al. (2010). The generated sequences were compared with other fungal DNA sequences from NCBI's GenBank sequence database using a blastn search. The sequences obtained from GenBank were manually aligned using Sequence Alignment Editor v. 2.0a11 (Rambaut 2002). Phylogenetic analyses of the aligned sequence data were performed using PAUP (Phylogenetic Analysis Using Parsimony) v. 4.0b10 (Swofford 2003). The parsimony analyses were run with alignment gaps treated as a fifth character state and all characters were unordered and of equal weight. Maximum parsimony analysis was performed using the heuristic search option with 100 random taxa additions and tree bisection and reconstruction (TBR) as the branch-swapping algorithm. Branches of zero length were collapsed and all multiple, equally parsimonious trees were saved. The robustness of the trees obtained was evaluated by 1000 bootstrap replications (Hillis and Bull 1993). The LSU alignment was analysed separately from the combined ITS/ TEF alignment. Tree length (TL), consistency index (CI), retention index (RI) and rescaled consistency index (RC) were calculated. Alignment gaps were treated as new character states. Novel sequence data were deposited in GenBank (Table 1) and the alignment in TreeBASE (http:// purl.org/phylo/treebase/phylows/study/TB2:S10979).

\section{Morphology}

Morphological descriptions are based on cultures sporulating on synthetic nutrient-poor agar (SNA; Crous et al. 2009 c) in vitro. Wherever possible, 30 measurements $(\times 1000$ magnification) were made of all taxonomically informative structures mounted in lactic acid, with the extremes of spore measurements given in parentheses. Colony colours (surface and reverse) were assessed after 1 month on MEA, PDA and OA at $25^{\circ} \mathrm{C}$ in the dark, using the colour charts of Rayner (1970).

\section{Results}

Phylogenetic analysis

Amplification products of approximately 1700 bases (ITS/ LSU) and 500 bases (TEF) were obtained for the isolates listed in Table 1. The LSU region of these sequences was used to obtain additional sequences from GenBank, which were added to the LSU alignment. Due to the inclusion of the shorter LSU sequences of Botryosphaeria sarmentorum (AY928052), Neofusicoccum luteum (AY928043), Neofusicoccum parvum (AY928045), Neofusicoccum ribis (AY928044), Pseudofusicoccum stromaticum (DQ377931) and Ramularia sp. (AY598911) in the alignment, it was not possible to subject the full length of the determined LSU sequences (Table 1) to the analysis. The manually adjusted LSU alignment contained 57 sequences (including the outgroup sequence) and, of the 561 characters used in the phylogenetic analysis, 229 were parsimony-informative, 31 were variable and parsimony-uninformative, and 301 were constant. The first 1000 equally most parsimonious trees $(\mathrm{TL}=801$ steps; $\mathrm{CI}=0.548 ; \mathrm{RI}=0.890 ; \mathrm{RC}=0.488)$, the first of which is shown in Fig. 2, were saved from the parsimony analysis of the LSU alignment. Analysis of the combined ITS/TEF alignment yielded the single most parsimonious tree shown in Fig. 3 ( $\mathrm{TL}=693$ steps; $\mathrm{CI}=0.922 ; \mathrm{RI}=0.846$; 


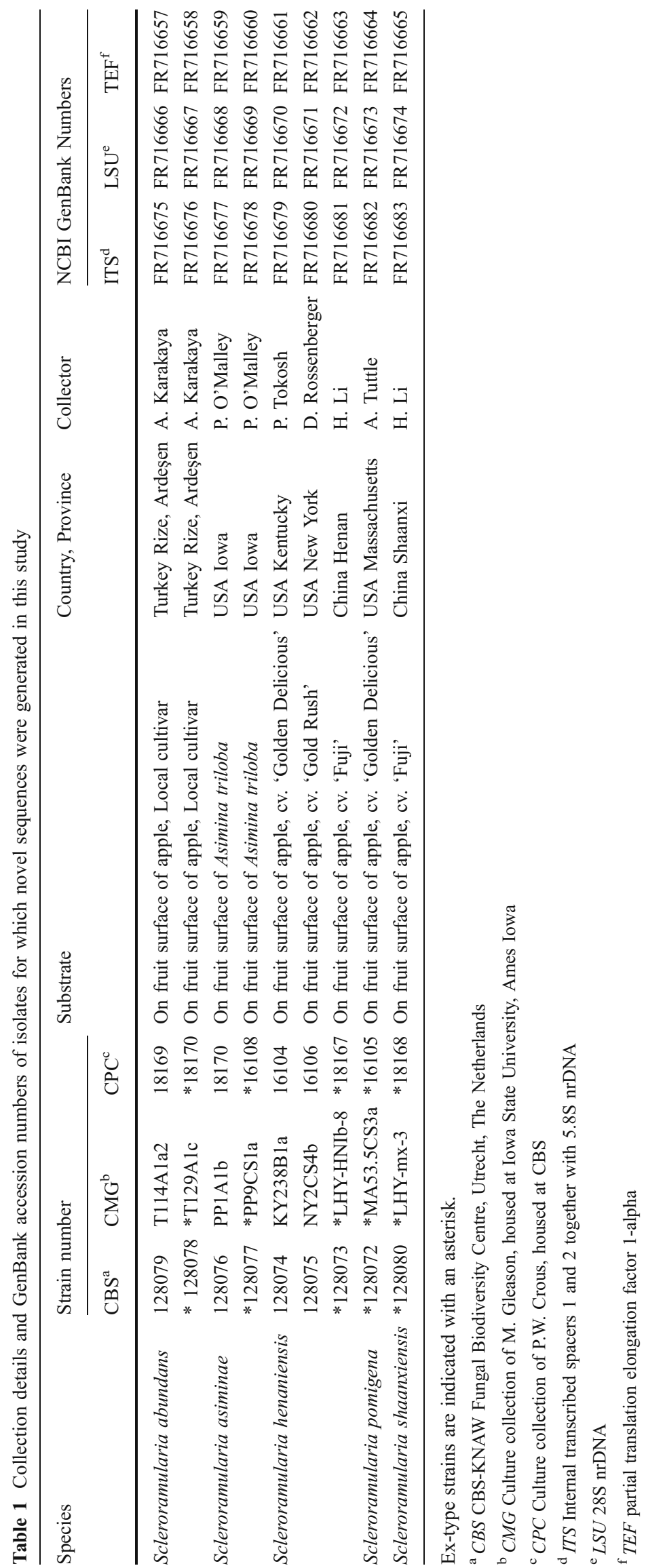




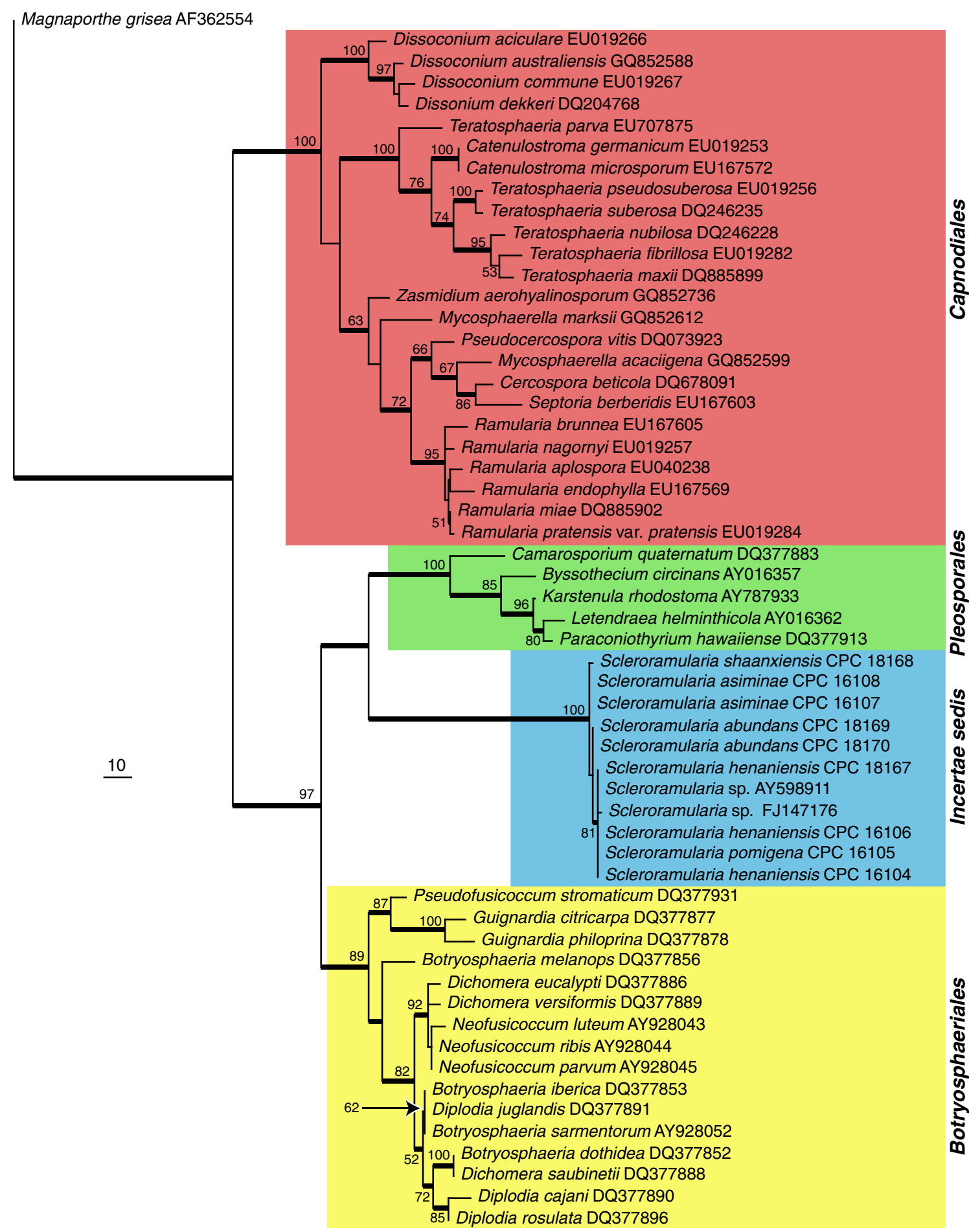

Fig. 2 The first of 1000 equally most parsimonious trees obtained from a heuristic search with 100 random taxon additions of the LSU sequence alignment. The scale bar shows 10 changes and bootstrap support values from 1000 replicates are shown at the nodes. The tree was rooted to Magnaporthe grisea (GenBank AF362554)
$\mathrm{RC}=0.780$ ). The manually adjusted combined ITS/TEF alignment contained 10 sequences (including the outgroup sequence) and, of the 1078 characters used in the phylogenetic analysis, 142 were parsimony-informative, 392 were variable and parsimony-uninformative, and 544 were constant. The results of the phylogenetic analyses are highlighted below under the taxonomic notes or in the Discussion, where applicable. 
Beauveria bassiana AY532027 / AY531936

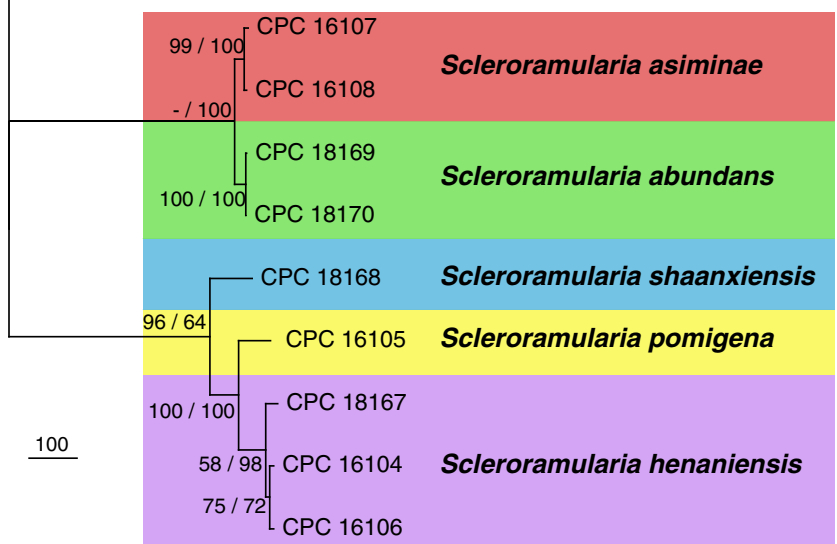

Fig. 3 The single most parsimonious trees obtained from a heuristic search with 100 random taxon additions of the combined ITS and TEF sequence alignment. The scale bar shows 100 changes and bootstrap support values from 1000 replicates are shown at the nodes (format: parsimony analysis/distance analysis with HKY85 substitution model). The tree was rooted to Beauveria bassiana (GenBank AY532027 and AY531936 for ITS and TEF, respectively)

\section{Taxonomy}

The present study resulted in the discovery of a novel genus of hyphomycetes in the Dothideomycetes containing several species that are associated with SBFS on apples and pawpaw. These taxa are treated below:

Scleroramularia Batzer \& Crous, gen. nov.

MycoBank MB517454

Etymology: Sclero-ramularia; after the presence of sclerotia, and its morphological similarity to the genus Ramularia.

Ramulariae morphologice valde similis, sed formatione sclerotiorum in cultura distinguitur.
Hyphomycetous. Mycelium creeping, superficial and submerged, consisting of hyaline, smooth, branched, septate, 1-2 $\mu \mathrm{m}$ diam hyphae. Conidiophores mostly reduced to conidiogenous cells, or with one supporting cell. Conidiogenous cells solitary, erect, intercalary on hyphae, subcylindrical, straight, with 1-2 terminal loci, rarely with a lateral locus; scars thickened, darkened and somewhat refractive. Conidia in branched chains, hyaline, smooth, finely guttulate, straight or gently curved if long and thin; basal conidia mostly narrowly cylindrical, 0-4septate; intercalary and terminal conidia becoming more narrowly ellipsoid to fusoid-ellipsoid, 0-4-septate, at times also anastomosing via hyphal bridges at ends of conidia; hila thickened, darkened and somewhat refractive. Commonly forming black, globose, sclerotium-like bodies superficially on the agar surface when cultivated.

Type species: Scleroramularia pomigena Batzer \& Crous, sp. nov.

Notes: Scleroramularia is morphologically similar to the genus Ramularia, but distinct in that it forms black sclerotia in culture and its conidia frequently remain attached in long chains. Kirschner (2009) recently used SEM to study the conidiogenesis of the genus Ramularia, and revealed it to have conidiogenous loci similar to the Cladosporium-type (circular rim with a central dome) (Bensch et al. 2010; Schubert et al. 2007). Scleroramularia has a similar conidiogenesis (Fig. 4), though conidia remain attached via a pore in the central dome for a much longer period than is the case in Ramularia, where the conidia dislodge quite easily. Phylogenetically, Scleroramularia is distinct from Ramularia (Capnodiales), forming a distinct lineage with closest sister taxa being those from Pleosporales and Botryosphaeriales (Fig. 1)
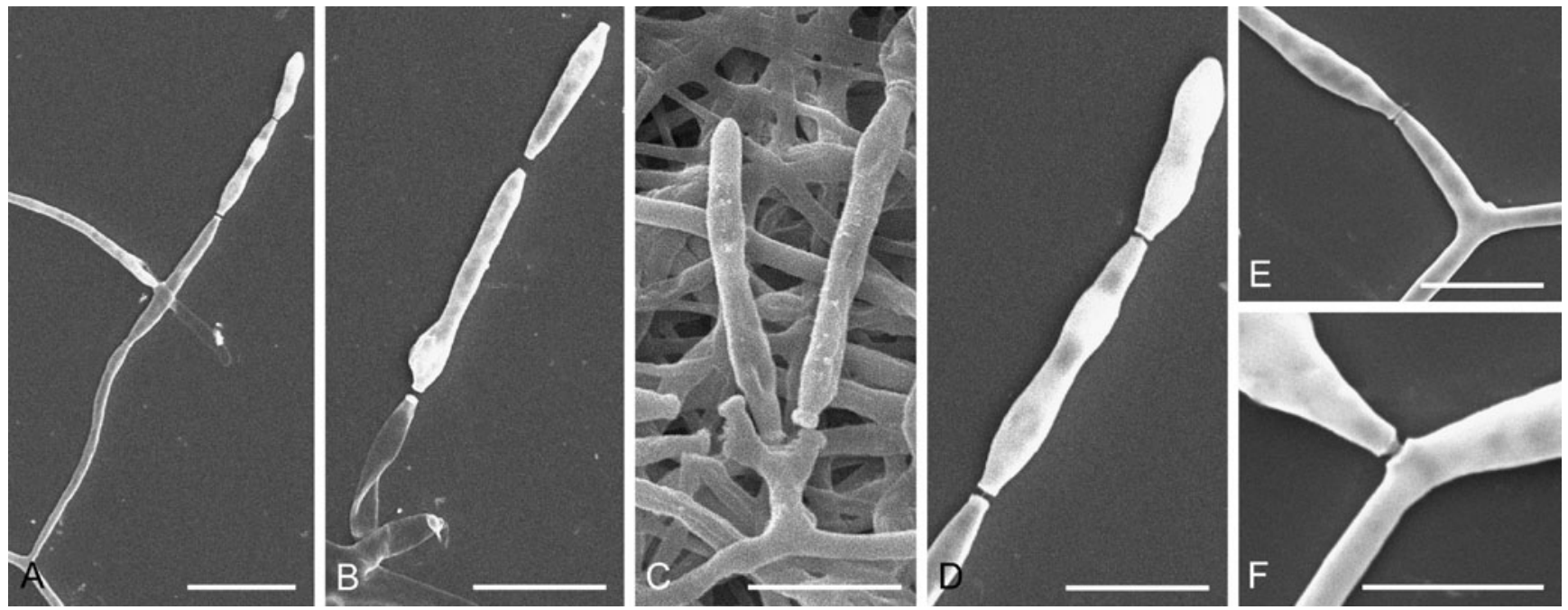

Fig. 4 Scanning electron micrographs of Scleroramularia spp. showing conidiogenesis, conidial hila and scars. A, B, D-F. S. shaanxiensis. C. S. henaniensis. Scale bars: $\mathrm{A}, \mathrm{B}=10 \mu \mathrm{m}, \mathrm{C}=5 \mu \mathrm{m}, \mathrm{D}-\mathrm{F}=5 \mu \mathrm{m}$ 

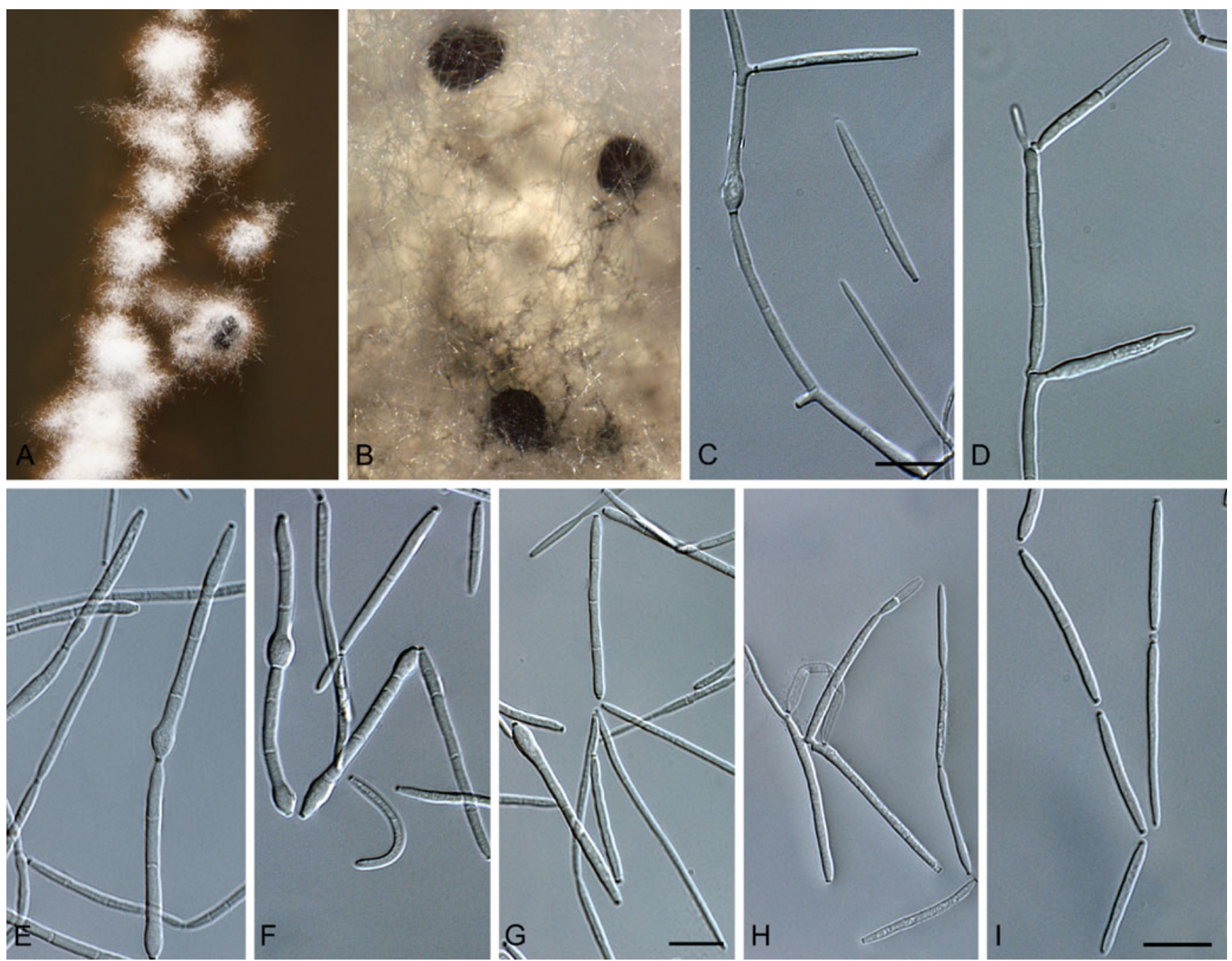

Fig. 5 Scleroramularia abundans (CPC 18170). A. Colony on malt extract agar. B. Colony on synthetic nutrient-poor agar (note sclerotia). C-I. Chains of conidia (note hyphal bridge in $\mathrm{H}$ ). Scale bars $=10 \mu \mathrm{m}$

Scleroramularia abundans Batzer, Mayfield \& Crous, sp. nov. Fig. 5

MycoBank MB517548.

Etymology: Named after its abundant sclerotial production in culture.

Scleroramulariae asiminae morphologice valde similis, sed formatione abunda sclerotiorum et coloniis olivaceo-griseis in cultura distinguitur.

On SNA. Mycelium creeping, superficial and submerged, consisting of hyaline, smooth, branched, septate, 1-2 $\mu \mathrm{m}$ diam hyphae. Conidiophores mostly reduced to conidiogenous cells, or with one supporting cell. Conidiogenous cells solitary, erect, intercalary on hyphae, subcylindrical, straight, with 1-2 terminal loci, rarely with a lateral locus, $2-10 \times 1.5-2.5 \mu \mathrm{m}$; scars thickened, darkened and somewhat refractive, $0.5-1 \mu \mathrm{m}$ wide. Conidia in branched chains, hyaline, smooth, finely guttulate, straight or gently curved if long and thin; basal conidia mostly narrowly cylindrical, but basal 2-3 conidia frequently obclavate, with an obconically truncate basal cell, $0-3$-septate, 35$80 \times 2.5-3.5(-5) \mu \mathrm{m}$; intercalary and terminal conidia subcylindrical to fusoid-ellipsoid, 0-3-septate, (22-)25$35(-43) \times(2-) 2.5(-3) \mu \mathrm{m}$; hila thickened and somewhat darkened, $0.5-1 \mu \mathrm{m}$.

Culture characteristics: Colonies after 2 weeks on SNA slow growing, spreading with sparse aerial mycelium and somewhat feathery margin, reaching $6 \mathrm{~mm}$ diam; surface white to olivaceous-grey in colour. On PDA spreading with sparse aerial mycelium and somewhat feathery margin, reaching $7 \mathrm{~mm}$ diam; surface white with patches of olivaceous-grey, reverse cinnamon, with patches of olivaceous-grey. On MEA slower growing, erumpent, sparse aerial mycelium, even to somewhat feathery margin, reaching $6 \mathrm{~mm}$ diam after 2 weeks; surface white with olivaceous-grey patches, reverse olivaceous-grey. On OA spreading with sparse aerial mycelium and even margin, surface olivaceous-grey, reaching $7 \mathrm{~mm}$ diam; black erumpent sclerotia forming on all media. 
Appearance on apple: Compact speck consisting of shiny, black, flattened sclerotium-like bodies, round to irregular (235-488 $\mu \mathrm{m}$ diam) appressed to the cuticle and less densely arranged $\left(2-6 / \mathrm{mm}^{2}\right)$ than $S$. henaniensis and S. pomigena.

Specimens examined: TURKEY, Rize, Ardeșen, on fruit surface of a local apple cultivar, Nov. 2008, A. Karakaya, CBS H-20483 holotype, ex-type cultures CPC $18170=$ T129A1c = CBS 128078; Rize, on fruit surface of apple cv. 'Rize-Ardesen', Nov. 2008, A. Karakaya, CPC $18169=$ $\mathrm{T} 114 \mathrm{~A} 1 \mathrm{a} 2=\mathrm{CBS} 128079$.

Notes: Unique features of $S$. abundans include its abundant sclerotial formation, and its colonies, which are olivaceous-grey on all media studied. Phylogenetically, $S$. abundans and the morphologically similar S. asiminae are distinct, with $99 \%$ (585/593 bases) and 93\% (427/463 bases) identity for ITS and TEF, respectively.

Scleroramularia asiminae Batzer, Hemnani \& Crous, sp. nov. Fig. 6

MycoBank MB517457.

Etymology: Named after the host from which it was collected, Asimina triloba.

Conidia basalia anguste cylindracea, 0-3-septata, 35$55 \times 1.5-2 \mu \mathrm{m}$; conidia intercalaria et terminalia anguste ellipsoidea vel fusoida-ellipsoidea, 0-3-septata, (13-)18-25 $(-30) \times(1.5-) 2(-2.5) \mu \mathrm{m}$.

On SNA. Mycelium creeping, superficial and submerged, consisting of hyaline, smooth, branched, septate, 1-2 $\mu \mathrm{m}$
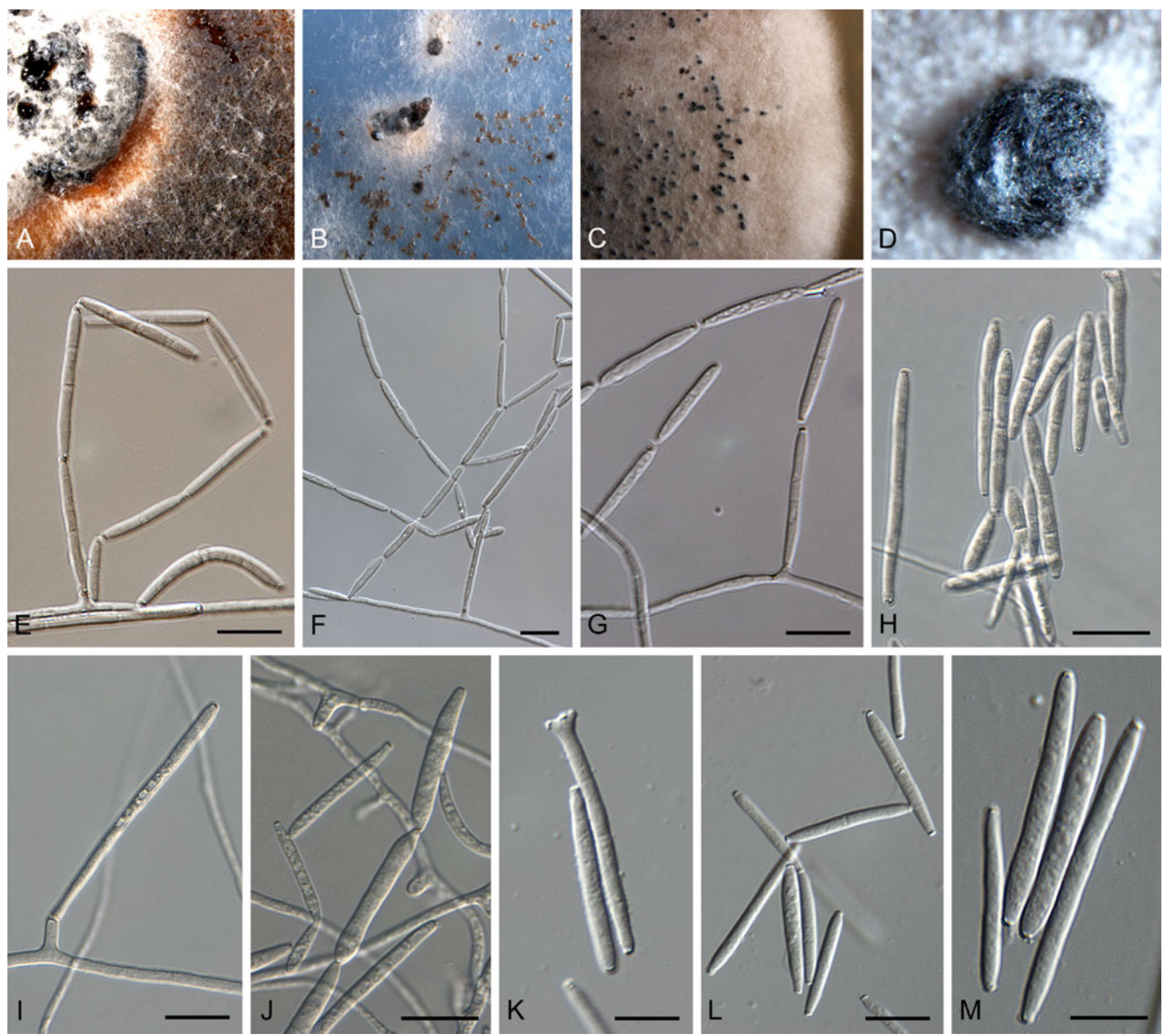

Fig. 6 Scleroramularia asiminae (CPC 16108). A. Colony on oatmeal agar. B. Colony on synthetic nutrient-poor agar. C. Colony on malt extract agar. D. Close-up of sclerotium. $\mathbf{E}-\mathbf{M}$. Conidiogenous cells giving rise to chains of conidia (note hila and scars). Scale bars $=10 \mu \mathrm{m}$ 
diam hyphae. Conidiophores mostly reduced to conidiogenous cells, or with one supporting cell. Conidiogenous cells solitary, erect, intercalary on hyphae, subcylindrical, straight, with 1-2 terminal loci, rarely with a lateral locus, 4-12×2-3 $\mu \mathrm{m}$; loci thickened, darkened and somewhat refractive, $1-1.5 \mu \mathrm{m}$ wide. Conidia in branched chains, hyaline, smooth, finely guttulate, straight or gently curved if long and thin; basal conidia mostly narrowly cylindrical, 0-3septate, $35-55 \times 1.5-2 \mu \mathrm{m}$; intercalary and terminal conidia becoming more narrowly ellipsoid to fusoid-ellipsoid, 0-3septate, $(13-) 18-25(-30) \times(1.5-) 2(-2.5) \mu \mathrm{m}$; hila thickened, darkened and somewhat refractive, $1-1.5 \mu \mathrm{m}$ wide.

Culture characteristics: After 2 weeks at $25^{\circ} \mathrm{C}$ sporulating profusely on SNA, white with abundant aerial mycelium, and black, globose, sclerotium-like bodies. On OA flattened, spreading, with sparse aerial mycelium, dirty white to cream, reaching $15 \mathrm{~mm}$ diam, with superficial sclerotium-like bodies formed. On MEA spreading, flattened, with sparse aerial mycelium, surface folded, olivaceous-grey in middle, white in outer region; reverse iron-grey in middle, orange in outer region, reaching $15 \mathrm{~mm}$ diam; surface white, reverse umber in centre and outer region. On PDA flattened, spreading, with sparse, whitish aerial mycelium; centre erumpent, with folded surface, and even margins; leaden-black to leaden-grey in middle due to sclerotial production, surrounded by orange and leaden-black zones, reaching $15 \mathrm{~mm}$ diam after $1 \mathrm{mo}$; reverse iron-grey in middle, orange in outer region.

Specimens examined: USA, Iowa, on fruit surface of Asimina triloba, Oct. 2007, P. O'Malley, CPC $16107=$ PP1A1b = CBS 128076; USA, Iowa, on fruit surface of Asimina triloba, Oct. 2007, P. O'Malley, CBS H-20479 holotype, ex-type cultures CPC $16108=$ PP9CS1a $=$ CBS 128077.

Notes: Particular features of this species are the black sclerotia formed on the agar surface (all media studied), and the hyphal bridges (anastomoses) that frequently occur between conidia arranged in long in conidial chains, causing conidia to remain attached to one another. These features are not exclusive, however, as the odd anastomosing conidium was also observed in some of the other species. For notes on the phylogeny, see Scleroramularia pomigena.

Scleroramularia henaniensis G.Y. Sun, H.Y. Li \& Crous, sp. nov. Fig. 7

MycoBank MB517456.

Etymology: Named after its type locality, Henan Province, China.

Scleroramulariae asiminae morphologice valde similis, sed conidiis brevioribus; conidiis basalibus, anguste cylindraceis, 1-3-septatis, $22-70 \times 1.5-2 \mu \mathrm{m}$; conidiis intercalaribus et terminalibus anguste ellipsoideis vel fusoidibus-ellipsoideis, $0-3$-septatis, $(7-) 12-17(-20) \times(1.5-) 2(-2.5) \mu \mathrm{m}$.
On SNA. Mycelium creeping, superficial and submerged, consisting of hyaline, smooth, branched, septate, 1-2 $\mu \mathrm{m}$ diam hyphae. Conidiophores mostly reduced to conidiogenous cells, or with one supporting cell. Conidiogenous cells solitary, erect, intercalary on hyphae, subcylindrical, straight, with 1-2 terminal loci, rarely with a lateral locus, $2-5 \times 2-3 \mu \mathrm{m}$; scars thickened, darkened and somewhat refractive, $0.5-1 \mu \mathrm{m}$ wide. Conidia in branched chains, hyaline, smooth, finely guttulate, straight or gently curved if long and thin; basal conidia mostly narrowly cylindrical, 1-3-septate, $22-70 \times 1.5-2 \mu \mathrm{m}$; intercalary and terminal conidia becoming more narrowly ellipsoid to fusoidellipsoid, 0-3-septate, (7-)12-17(-20) × (1.5-)2(-2.5) $\mu \mathrm{m}$; hila thickened, darkened and somewhat refractive, $0.5-1 \mu \mathrm{m}$ wide.

Culture characteristics: After 2 weeks at $25^{\circ} \mathrm{C}$ sporulating profusely on SNA, white with abundant aerial mycelium, reaching $20 \mathrm{~mm}$ diam. On OA flattened, spreading, with sparse aerial mycelium, and even, raised margins, white, reaching $20 \mathrm{~mm}$ diam. On MEA spreading, flattened, with sparse aerial mycelium, surface white, ridged, with feathery margin; reverse umber in middle, orange to sienna in outer region, reaching $15 \mathrm{~mm}$ diam; surface white, reverse umber in centre and outer region. On PDA flattened, spreading, with moderate aerial mycelium, and feathery margin; surface cream to white, reverse umber in middle, sienna in outer region, reaching $20 \mathrm{~mm}$ diam after 2 weeks. Black, globose bodies (sclerotia), variable in size, are sparsely formed on MEA and PDA.

Appearance on apple: Compact speck consisting of shiny, black, flattened sclerotium-like bodies, round to irregular (35-418 $\mu \mathrm{m}$ diam) appressed to the cuticle and densely arranged $\left(5-22 / \mathrm{mm}^{2}\right)$ with irregular margins.

Specimen examined: CHINA, Henan Province, Lingbao, on fruit surface of apple cv. 'Fuji', 6. Oct. 2006, H. Li, CBS H-20481 holotype, ex-type cultures CPC $18167=06-$ LHYHNIb-8 = CBS 128073. USA, Kentucky, on fruit surface of apple cv. 'Golden Delicious', Sept. 2005, P. Tokosh, CPC $16104=\mathrm{KY} 238 \mathrm{~B} 1 \mathrm{a}=\mathrm{CBS}$ 128074; USA, New York, on fruit surface of apple cv. 'Gold Rush', Oct. 2005, D. Rosenberger, CPC $16106=$ NY2CS4b $=$ CBS 128075.

Notes: Scleroramularia henaniensis is similar to $S$. asiminae, but has shorter conidia, does not form sclerotia on SNA (but these form sparsely on MEA and PDA), and anastomoses between conidial ends were not observed. Phylogenetically, these two species are also distinct, with 97\% (577/595 bases) and 87\% (363/418 bases) identity for ITS and TEF, respectively. However, it is possible that the strains shown in Fig. 3 for this species represent a species complex, and that the two strains obtained in the U.S.A. (CPC 16104, 16106) represent yet another taxon. The intraspecific identity for the species is $99 \%$ on ITS $(590 / 593$ bases and 978/985 bases when compared to CPC 16104 and 16106 , respectively) and $96 \%$ or $95 \%$ on TEF (449/472 

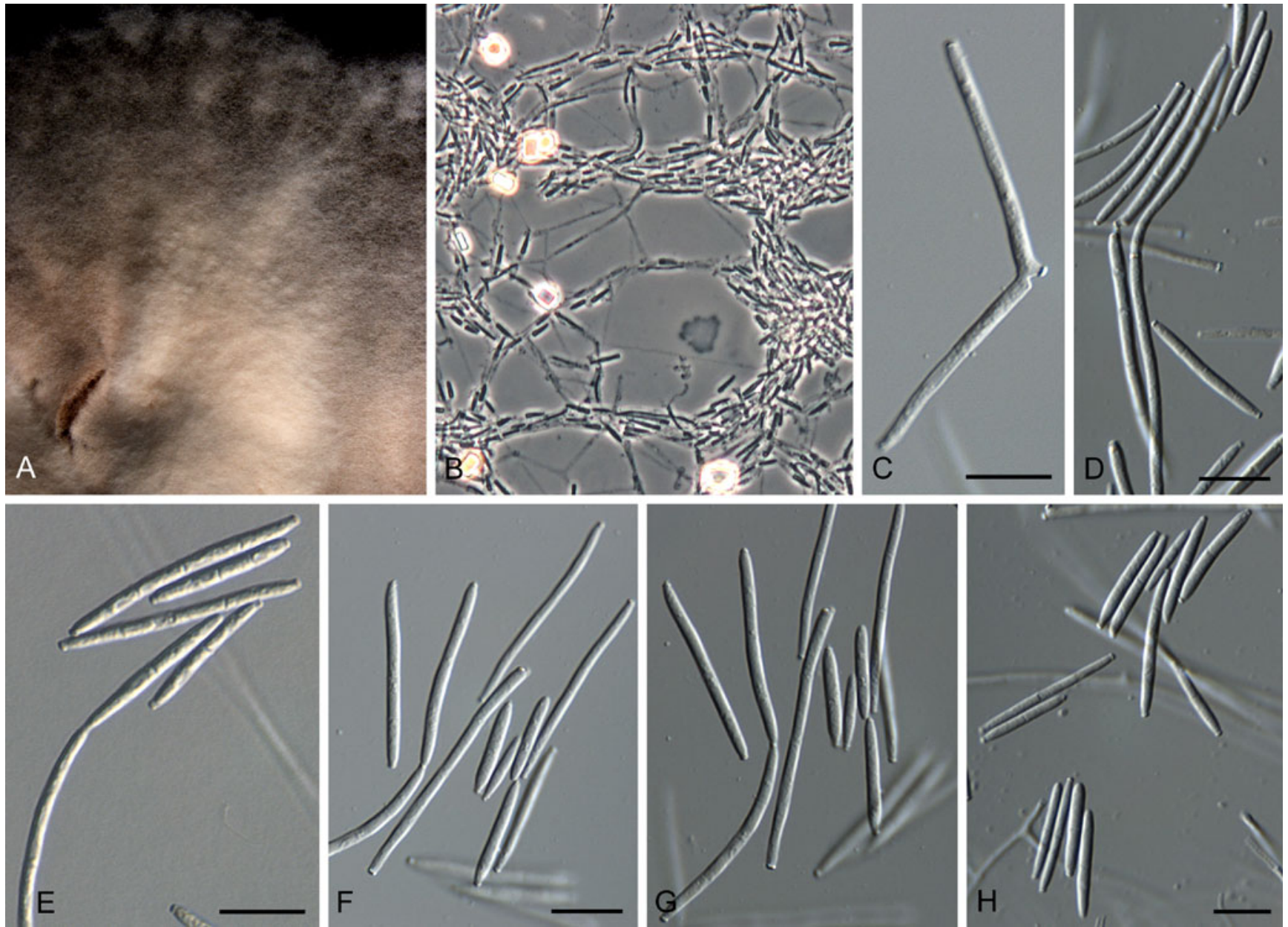

Fig. 7 Scleroramularia henaniensis (CPC 18167). A. Colony on malt extract agar. B. fragmenting conidia in older cultures on synthetic nutrientpoor agar. C. Two conidia joined by hyphal bridge (anastomosis). D-H. Disarticulating conidial chains. Scale bars $=10 \mu \mathrm{m}$

bases and 448/472 bases when compared to CPC 16104 and 16106, respectively). In spite of this variation, we prefer to treat these three isolates as representative of a single taxon, S. henaniensis, pending the collection of additional isolates.

Scleroramularia pomigena Batzer \& Crous, sp. nov. Fig. 8

MycoBank MB517455.

Etymology: Named after its occurrence on apple fruit.

Scleroramulariae asiminae morphologice valde similis, sed conidiis brevioribus, conidiis basalibus anguste cylindraceis, 0-3-septatis, $35-70 \times 1.5-2 \mu \mathrm{m}$; conidiis intercalaribus et terminalibus anguste ellipsoideis vel fusoidibus-ellipsoideis, $0-3$-septatis, $(10-) 12-25(-30) \times(1.5-) 2.5(-3) \mu \mathrm{m}$.

On SNA. Mycelium creeping, superficial and submerged, consisting of hyaline, smooth, branched, septate, $1-2 \mu \mathrm{m}$ diam hyphae. Conidiophores mostly reduced to conidiogenous cells, or with one supporting cell. Conidiogenous cells solitary, erect, intercalary on hyphae, subcylindrical, straight, with $1-2$ terminal loci, rarely with a lateral locus, $8-17 \times 2-$
$3 \mu \mathrm{m}$; scars thickened, darkened and somewhat refractive, $1-$ $1.5 \mu \mathrm{m}$ wide. Conidia in branched chains, hyaline, smooth, finely guttulate, straight or gently curved if long and thin; basal conidia mostly narrowly cylindrical, $0-3$-septate, 35$70 \times 1.5-2 \mu \mathrm{m}$; intercalary and terminal conidia becoming more narrowly ellipsoid to fusoid-ellipsoid, $0-3$-septate, (10-) $12-25(-30) \times(1.5-) 2.5(-3) \mu \mathrm{m}$; hila thickened, darkened and somewhat refractive, $1-1.5 \mu \mathrm{m}$ wide.

Culture characteristics: After 2 weeks at $25^{\circ} \mathrm{C}$ sporulating profusely on SNA, white with abundant aerial mycelium. On OA flattened, spreading, with sparse aerial mycelium, and even, raised margins, white, reaching $20 \mathrm{~mm}$ diam. On MEA spreading, flattened, surface folded with sparse aerial mycelium, margin somewhat crenate, reaching $20 \mathrm{~mm}$ diam; surface white, reverse umber in centre and outer region. On PDA flattened, spreading, with moderate, dense aerial mycelium, and even margin; surface white, reverse orange to umber, reaching $20 \mathrm{~mm}$ diam after 2 weeks. Black, globose bodies (sclerotia) up to $100 \mu \mathrm{m}$ diam are formed on MEA and PDA. 

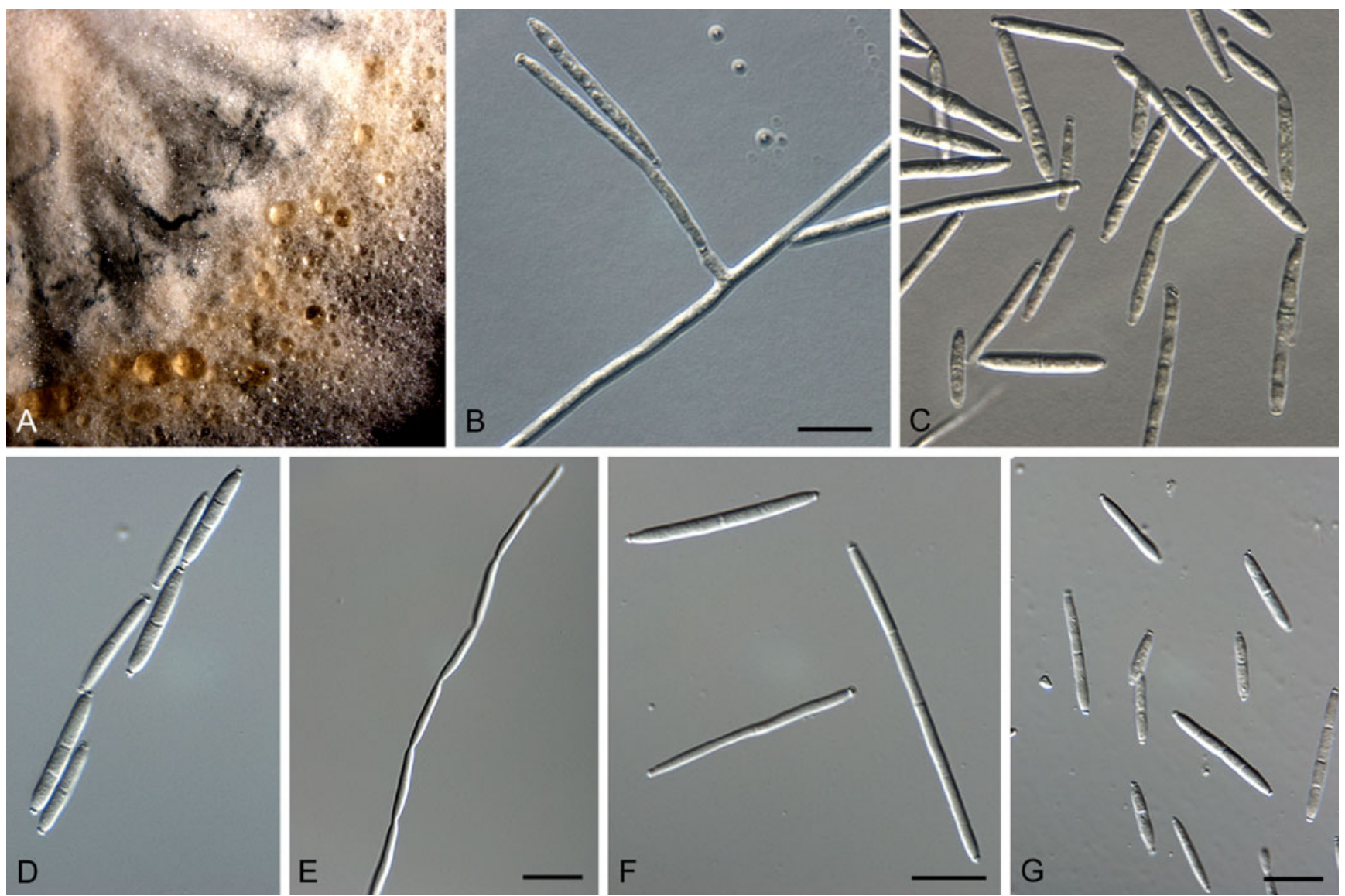

Fig. 8 Scleroramularia pomigena (CPC 16105). A. Colony on malt extract agar. B. Conidiogenous cell giving rise to conidia. C-G. Disarticulating chains of conidia. Scale bars $=10 \mu \mathrm{m}$

Appearance on apple: Compact speck consisting of shiny, black, flattened sclerotium-like bodies, round to irregular $(32-41 \mu \mathrm{m}$ diam) appressed to the cuticle and densely arranged $\left(4-18 / \mathrm{mm}^{2}\right)$ with irregular margins.

Specimen examined: USA, Massachusetts, on fruit surface of apple cv. 'Golden Delicious', Oct. 2005, A. Tuttle, CBS H-20480 holotype, ex-type cultures CPC $16105=$ MA53.5CS3a $=$ CBS 128072 .

Notes: Scleroramularia pomigena is similar to $S$. asiminae in morphology, but does not form sclerotia on SNA (but these are present on MEA and PDA), and anastomoses between conidial ends were not observed. Conidia are also slightly shorter and wider than in $S$. asiminae. Phylogenetically, these two species are also distinct, with $97 \%$ (582/603 bases) and 87\% (390/453 bases) identity for ITS and TEF, respectively.

Scleroramularia shaanxiensis G.Y. Sun, H.Y. Li \& Crous, sp. nov. Fig. 9

MycoBank MB517459.

Scleroramulariae asiminae morphologice similis, sed conidiis brevioribus; conidiis basalibus, anguste cylindraceis, 0-3-septatis, $30-55 \times 1.5-2 \mu \mathrm{m}$; conidiis intercalaribus et terminalibus subcylindraceis vel anguste fusoidibusellipsoideis, 0-3-septatis, (16-)22-30(-40) $\times(1-) 1.5(-2) \mu \mathrm{m}$.

Etymology. Named after its type locality, Shaanxi Province, China.

On SNA. Mycelium creeping, superficial and submerged, consisting of hyaline, smooth, branched, septate, 1-2 $\mu \mathrm{m}$ diam hyphae. Conidiophores mostly reduced to conidiogenous cells, or with one supporting cell. Conidiogenous cells solitary, erect, intercalary on hyphae, subcylindrical, straight, with 1-2 terminal loci, rarely with a lateral locus, $2-7 \times 1.5-2 \mu \mathrm{m}$; scars thickened, darkened and somewhat refractive, $0.5-1 \mu \mathrm{m}$ wide. Conidia in branched chains, hyaline, smooth, finely guttulate, straight or gently curved if long and thin; basal conidia narrowly cylindrical, $0-3$ septate, $30-55 \times 1.5-2 \mu \mathrm{m}$; intercalary and terminal conidia subcylindrical to narrowly fusoid-ellipsoid, 0-3-septate, $(16-) 22-30(-40) \times(1-) 1.5(-2) \mu \mathrm{m}$; hila thickened, darkened and somewhat refractive, $0.5-1 \mu \mathrm{m}$ wide.

Culture characteristics: Colonies after 2 weeks on SNA spreading with sparse aerial mycelium, and feathery margins, reaching $20 \mathrm{~mm}$ diam; surface white to cream in colour. On PDA spreading with sparse aerial mycelium and 

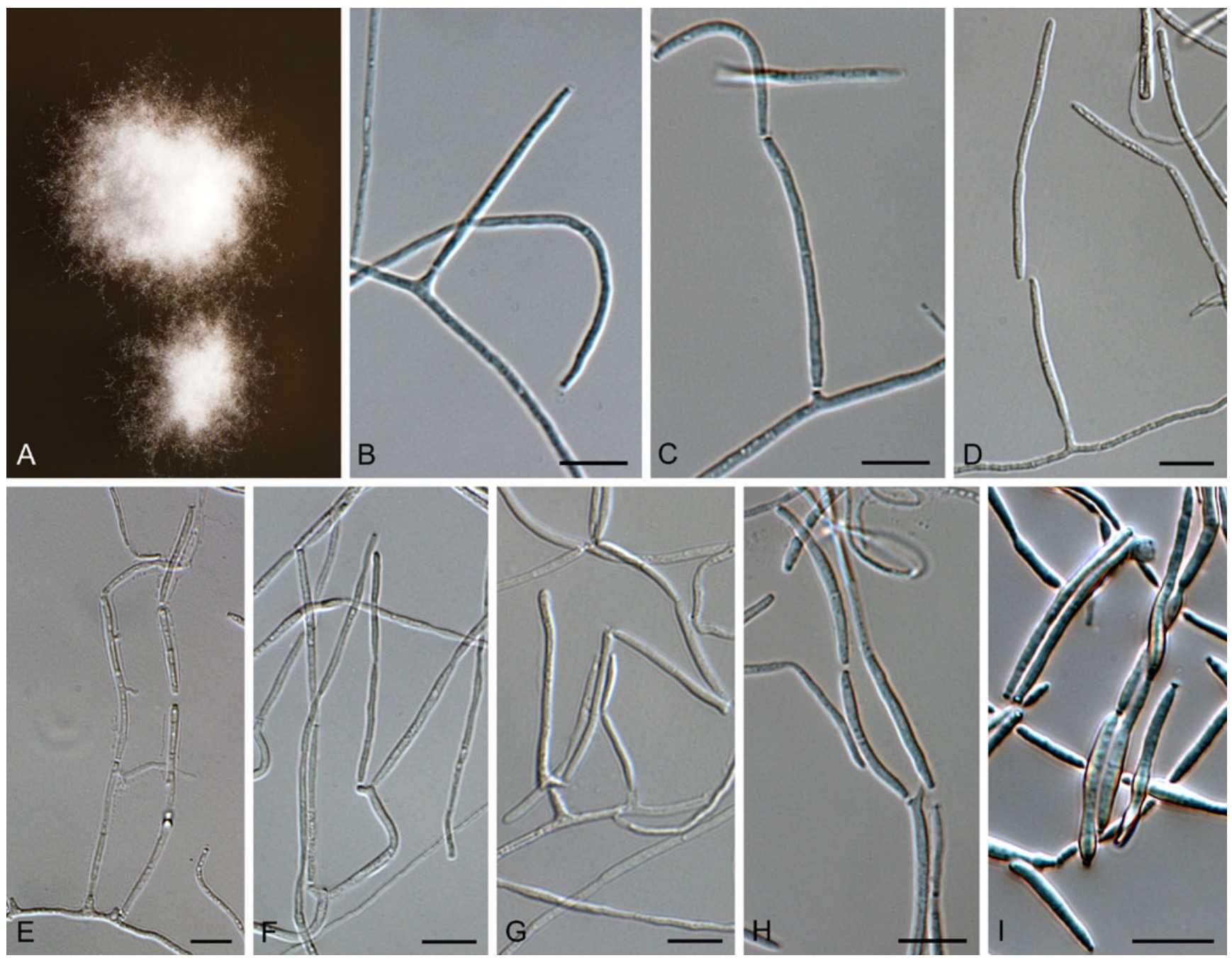

Fig. 9 Scleroramularia shaanxiensis (CPC 18168). A. Colonies on malt extract agar. B-G. Conidiogenous cells giving rise to chains of conidia. H, I. Conidia. Scale bars $=10 \mu \mathrm{m}$

feathery margins; surface white to cream, and cinnamon underneath; reaching $15 \mathrm{~mm}$ diam. On OA surface white to cream, reaching $15 \mathrm{~mm}$ diam; no sclerotia observed.

Specimen examined: CHINA, Shaanxi Province, Mei County, 107.7321, 34.239, on fruit surface of apple cv. 'Fuji', 6 Oct. 2006, H. Li, CBS H-20482 holotype, ex-type cultures CPC $18168=06-$-LHY-mx-3 = CBS 128080.

Notes: Distinguishing features of $S$. shaanxiensis include that its basal conidia are shorter than $55 \mu \mathrm{m}$ in length, and that its colonies are white to cream on PDA. Phylogenetically, this species is clearly distinct from all other species included in this study (Fig. 2).

\section{Discussion}

The genus Ramularia, which is based on $R$. pusilla, has been linked to the teleomorph genus Mycosphaerella
(Mycosphaerellaceae, Capnodiales, Dothideomycetes), which is again based on M. punctiformis (anamorph: $R$. endophylla) (Verkley et al. 2004). Although the genus Mycosphaerella is polyphyletic (Crous et al. 2007, 2009a, b; Schoch et al. 2006, 2009), the genus Ramularia represents a monophyletic entity within the Mycosphaerellaceae (Crous et al. 2009a, b). Although conidiogenous loci of Scleroramularia appear to have a similar morphology to that observed in Ramularia (Kirschner 2009) (Fig. 4), conidial chains remain intact for longer, being linked via the pore in their central dome, while this is not observed in Ramularia, where conidial chains break free much sooner. Phylogenetically, Scleroramularia appears to represent an undescribed order in the Dothideomycetes, between the Pleosporales and Botryosphaeriales.

Braun (1995) provided a key to several Ramularia-like genera, which occur on numerous hosts, and range in ecology from being saprobic to hyperparasitic or plant 
pathogenic. Genera with pycnidial to acervular conidiomata such as Septoria/Phloeospora, Phloeosporella and Pseudocercosporella are clearly distinct from Scleroramularia, which forms its conidia on superficial mycelium in culture (also mycelial plaques on fruit). Several hyphomycete genera have hyaline structures, conidia arranged in chains, and darkened, thickened, somewhat refractive loci, resembling Scleroramularia. Helgardia (teleom. Oculimacula), Microdochium, Mycocyclosporella, Neoramularia and Thedgonia all have unthickened conidial scars (Braun 1995, 1998; Robbertse et al. 1995; Crous et al. 2003, 2009a, b; Frank et al. 2010). The most similar to Scleroramularia is Ramularia, incl. Ovularia with its aseptate conidia (Crous 2009), Tretovularia, Neoovularia, Ramulariopsis and the synnematous Phacellium (Braun 1995, 1998), having hyaline conidiophores and branched conidial chains, with somewhat darkened, refractive scars. None of these genera, however, produce sclerotia, and are therefore distinct from Scleroramularia.

The discovery of Scleroramularia as a new, potentially species-rich genus of epiphytic fungi occurring on fruit surfaces of different hosts suggests that many unexplored niches still await to be sampled. Furthermore, a diverse range of different epiphytic fungi, representing several novel genera, has recently been reported to be associated with SBFS (Frank et al. 2010; Yang et al. 2010). The fact that fungi occurring in different plant parts appear to be ecologically and genetically separated suggests that as more species of fruit are sampled, we will gain a better understanding of the species associated with SBFS, their host range, distribution and ecology.

\section{Key to species of Scleroramularia*}

1. Basal conidia longer than $55 \mu \mathrm{m}$ in length 2

1. Basal conidia up to $55 \mu \mathrm{m}$ in length 4

2. Intercalary and terminal conidia up to $20 \mu \mathrm{m}$ long, $(7-) 12-17(-20) \times(1.5-) 2(-2.5) \mu \mathrm{m}$

S. henaniensis

2. Intercalary and terminal conidia longer than $20 \mu \mathrm{m}$ ... 3

3. Basal conidia narrowly cylindrical, up to $2 \mu \mathrm{m}$ wide, intercalary and terminal conidia $(10-) 12-25(-30) \times$ $(1.5-) 2.5(-3) \mu \mathrm{m}$ S. pomigena

3. Basal conidia narrowly cylindrical to obclavate, $2.5-3.5$ $(-5) \mu \mathrm{m}$ wide; intercalary and terminal conidia (22-) $25-35(-43) \times(2-) 2.5(-3) \mu \mathrm{m}$..... S. abundans

4. After 2 weeks on PDA, surface cream to white S. shaanxiensis
4. After 2 weeks on PDA, surface leaden-black to leadengrey in middle, surrounded by orange and leaden-black zones S. asiminae

*Sporulating on SNA in culture.

Acknowledgements This work was supported by National Natural Science Foundation of China (30771735), the 111 Project from Education Ministry of China (B07049), and Top Talent Project of Northwest A\&F University. The authors thank the technical staff, A. van Iperen (cultures), M. Vermaas (photo plates), and M. StarinkWillemse (DNA isolation, amplification and sequencing) for their invaluable assistance. Thank you to Derrick Mayfield and Jennifer Blaser for technical assistance. Thanks are also extended to members of the Ministry of Agriculture and Rural Affairs, Rize Branch, Turkey for their help during this study.

Open Access This article is distributed under the terms of the Creative Commons Attribution Noncommercial License which permits any noncommercial use, distribution, and reproduction in any medium, provided the original author(s) and source are credited.

\section{References}

Batzer JC, Gleason ML, Harrington TC, Tiffany LH (2005) Expansion of the sooty blotch and flyspeck complex on apples based on analysis of ribosomal DNA gene sequences and morphology. Mycologia 97(6):1268-1286

Batzer JC, Arias MM, Harrington TC, Gleason ML, Groenewald JZ, Crous PW (2008) Species of Zygophiala (Schizothyriaceae, Capnodiales) are associated with the sooty blotch and flyspeck complex on apple. Mycologia 100(2):246-258

Bensch K, Groenewald JZ, Dijksterhuis J, Starink-Willemse M, Andersen B, Summerell BA, Shin H-D, Dugan FM, Schroers H-J, Braun U, Crous PW (2010) Species and ecological diversity within the Cladosporium cladosporioides complex (Davidiellaceae, Capnodiales). Stud Mycol 67:1-94

Blaser JM, Karakaya A, Mayfield DA, Batzer JC, Gleason ML (2010) Diversity of sooty blotch and flyspeck fungi from apples in northeastern Turkey. Phytopathology (Abstr) 100(6): S15

Braun U (1995) A monograph of Cercosporella, Ramularia and allied genera (Phytopathogenic Hyphomycetes), vol 1. IHW-Verlag, München, Germany

Braun U (1998) A monograph of Cercosporella, Ramularia and allied genera (Phytopathogenic Hyphomycetes), vol 2. IHW-Verlag, München, Germany

Colby AS (1920) Sooty blotch of pomaceous fruits. Trans Ill State Acad Sci 13:139-179

Crous PW (2009) Taxonomy and phylogeny of the genus Mycosphaerella and its anamorphs. Fungal Divers 38:1-24

Crous PW, Groenewald JZ, Gams W (2003) Eyespot of cereals revisited: ITS phylogeny reveals new species relationships. Eur J Plant Pathol 109:841-850

Crous PW, Gams W, Stalpers JA, Robert V, Stegehuis G (2004) MycoBank: an online initiative to launch mycology into the 21st century. Stud Mycol 50:19-22

Crous PW, Braun U, Groenewald JZ (2007) Mycosphaerella is polyphyletic. Stud Mycol 58:1-32

Crous PW, Schoch CL, Hyde KD, Wood AR, Gueidan C, de Hoog GS, Groenewald JZ (2009a) Phylogenetic lineages in the Capnodiales. Stud Mycol 64:17-47 
Crous PW, Summerell BA, Carnegie AJ, Wingfield MJ, Hunter GC, Burgess TI, Andjic V, Barber PA, Groenewald JZ (2009b) Unravelling Mycosphaerella: do you believe in genera? Persoonia 23:99-118

Crous PW, Verkleij GJM, Groenewald JZ, Samson RA (eds) (2009c) Fungal biodiversity. CBS Laboratory Manual Series. Centraalbureau voor Schimmelcultures, Utrecht

Díaz Arias MM, Batzer JC, Harrington TC, Wong AW, Bost SC, Cooley DR, Ellis MA, Hartman JR, Rosenberger DA, Sundin GW, Sutton TB, Travis JW, Wheeler MJ, Yoder KS, Gleason ML (2010) Diversity and biogeography of sooty blotch and flyspeck fungi on apple in the eastern and midwestern United States. Phytopathology 100:345-355

Frank J, Crous PW, Groenewald JZ, Oertel B, Hyde KD, Phengsintham P, Schroers H-J (2010) Microcyclospora and Microcyclosporella: novel genera accommodating epiphytic fungi causing sooty blotch on apple. Persoonia 24:93-105

Hillis DM, Bull JJ (1993) An empirical test of bootstrapping as a method for assessing confidence in phylogenetic analysis. Syst Biol 42:182-192

Johnson EM, Sutton TB (1994) First report of Geastrumia polystimgatis on apple and common blackberry in North America. Plant Dis 78:1219

Johnson EM, Sutton TB, Hodges CS (1996) Peltaster fructicola: a new species in the complex of fungi causing apple sooty blotch. Mycologia 88:114-120

Kirschner R (2009) Cercosporella and Ramularia. Mycologia 101:110-119

Li HY, Zhang R, Sun GY, Batzer JC, Gleason ML (2010) New species and record of Zygophiala on apple fruit from China. Mycol Progress 9:245-251

Lombard L, Crous PW, Wingfield BD, Wingfield MJ (2010) Phylogeny and systematics of the genus Calonectria. Stud Mycol 66:31-69

Ma YQ, Zhang R, Sun GY, Zhu HX, Tang M, Batzer JC, Gleason ML (2010) A new species of Zygophiala associated with the flyspeck complex on apple from China. Mycol Progress 9:151155

Rambaut A (2002) Sequence alignment editor. Version 2.0. Department of Zoology, University of Oxford, Oxford, UK. Software distributed by author (http://tree.bio.ed.ac.uk/software/seal)

Rayner RW (1970) A mycological colour chart. Commonwealth Mycological Institute, Kew, Surry. British Mycological Society

Robbertse B, Campbell GF, Crous PW (1995) Revision of Pseudocercosporella-like species causing eyespot disease of wheat. S Afr J Bot 61:43-48
Schoch CL, Shoemaker RA, Seifert KA, Hambleton S, Spatafora JW, Crous PW (2006) A multigene phylogeny of the Dothideomycetes using four nuclear loci. Mycologia 98:1043-1054

Schoch CL, Crous PW, Groenewald JZ, Boehm EWA, Burgess TI, de Gruyter J, de Hoog GS, Dixon LJ, Grube M, Gueidan C, Harada Y, Hatakeyama S, Hirayama K, Hosoya K, Hyde KD, Jones EBG, Kohlmeyer J, Li YM, Kruys Å, Lücking R, Lumbsch HT, Lutzoni F, Marvanová L, McVay AH, Mbatchou JS, Miller AN, Mugambi GK, Muggia L, Nelsen MP, Nelson P, Owensby CA, Li YM, Phillips AJL, Phongpaichit S, Pointing SB, Pujade-Renaud V, Raja HA, Rivas Plata E, Robbertse B, Ruibal C, Sakayaroj J, Sano T, Selbmann L, Shearer CA, Shirouzu T, Slippers B, Suetrong S, Tanaka K, Volkmann-Kohlmeyer B, Wingfield MJ, Wood AR, Woudenberg JHC, Yonezawa H, Zhang Y, Spatafora JW (2009) A class-wide phylogenetic assessment of Dothideomycetes. Stud Mycol 64:1-15

Schubert K, Groenewald JZ, Braun U, Dijksterhuis J, Starink M, Hill CF, Zalar P, de Hoog GS, Crous PW (2007) Biodiversity in the Cladosporium herbarum complex (Davidiellaceae, Capnodiales), with standardisation of methods for Cladosporium taxonomy and diagnostics. Stud Mycol 58:105-156

Sun GY, Zhang R, Zhang Z, Zhang M (2003) Isolation of sooty blotch and flyspeck fungi from apple surface by picking up the thalli. Acta Phytopathol Sinica 33:479-480 [in Chinese]

Swofford DL (2003) PAUP*. Phylogenetic analysis using parsimony (* and their methods). Version 4.0. Sinauer Associates, Sunderland, Massachusetts, USA

Verkley GJM, Crous PW, Groenewald JZ, Braun U, Aptroot A (2004) Mycosphaerella punctiformis revisited: morphology, phylogeny, and epitypification of the type species of the genus Mycosphaerella (Dothideales, Ascomycota). Mycol Res 108:1271-1282

Williamson SM, Sutton TB (2000) Sooty blotch and flyspeck of apple: etiology, biology, and control. Plant Dis 84(7):714- 724

Yang HL, Sun GY, Batzer JC, Crous PW, Groenewald JZ, Gleason ML (2010) Novel fungal genera and species associated with the sooty blotch and flyspeck complex on apple in China and the USA. Persoonia 24:29-37

Zhai XR, Li HY, Zhang R, Sun GY, Tang M, Batzer JC, Gleason ML (2008) Zygophiala (hyphomycetes) - a genus newly recorded from China. Mycotaxon 105:325-330

Zhang R, Zhang Z, Zhai XR, Zhang M, Sun GY, Gleason ML (2007) A new species of Dissoconium from China colonizing apples. Mycotaxon 101:165-172

Zhang R, Yang HL, Sun GY, Li HY, Zhuang JL, Zhai XR, Gleason ML (2009) Strelitziana mali, a new species causing sooty blotch on apple fruit. Mycotaxon 110:477-485 